\title{
PI3K Gene Mutation
}

National Cancer Institute

\section{Source}

National Cancer Institute. PI3K Gene Mutation. NCI Thesaurus. Code C157554.

A change in the nucleotide sequence in a PI3K family gene. 